\title{
Területi kutatások Közép-Európában - Beszámoló a Magyar Regionális Tudományi Társaság XVII. vándorgyüléséről
}

\section{Territorial research in Central Europe - Report on the 17th Annual Meeting of the Hungarian Regional Science Association}

\author{
KOVÁCS SÁNDOR ZSOLT, RÁCZ SZILÁRD
}

\begin{abstract}
KOVÁCS Sándor Zsolt: tudományos segédmunkatárs, Közgazdaság- és Regionális Tudományi Kutatóközpont, Regionális Kutatások Intézete; 7621 Pécs, Papnövelde u. 22.; skovacs@rkk.hu; https://orcid.org/0000-0001-6612-6296

RÁCZ Szilárd: tudományos munkatárs, Közgazdaság-és Regionális Tudományi Kutatóközpont, Regionális Kutatások Intézete; 7621 Pécs, Papnövelde u. 22.; szracz@rkk.hu; https://orcid.org/0000-0002-9397-2620
\end{abstract}

\begin{abstract}
Sándor Zsolt KOVÁCS: junior research fellow, Institute for Regional Studies, Centre for Economic and Regional Studies; Papnövelde u. 22., H-7621 Pécs, Hungary; skovacs@rkk.hu; https://orcid.org/0000-0001-6612-6296

Szilárd RÁCZ: research fellow, Institute for Regional Studies, Centre for Economic and Regional Studies; Papnövelde u. 22., H-7621 Pécs, Hungary; szracz@rkk.hu; https://orcid.org/0000-00029397-2620
\end{abstract}

A Magyar Regionális Tudományi Társaság 2019. évi vándorgyűlése a CERS konferenciát (7th Central European Conference in Regional Science, 2019. október 9-11.) követően került megrendezésre, a konferencia és a vándorgyűlés házigazdája egyaránt a Soproni Egyetem Lámfalussy Sándor Közgazdaságtudományi Kara volt. Az MRTT jelen lévő tagjai 2019. október 11-én délután a közép-európai területi kutatások egyes aspektusait vitatták meg. A két rendezvény közvetlen közelsége miatt, a hagyományoktól eltérően, a vándorgyülésen plenáris előadásokra és angol nyelvü szekcióülésekre nem került sor, a közgyülést követően párhuzamos szekciókban folyt a munka.

A közgyűlés elején Gál Zoltán elnök kérésére a résztvevők megemlékeztek Csatári Bálintról, az MRTT alapító tagjáról, aki 2019 szeptemberében, 70 éves korában hunyt el.

A 2015. évi rendes és a 2017. évi részleges tisztújításon mandátumot kapott tisztségviselők megbízatása lejárt, így a közgyűlés keretében a Társaság megválasztotta a következő négyéves időtartamra a tisztségviselőket. A szavazáson a 190 aktív (tagdíját a közgyűlésig rendező) MRTT-tagból 54 fö vett részt, összesen tizenhat tisztségviselői helyről szavaztak a megjelentek. A közgyűlés döntése alapján hat új és tíz újraválasztott tisztségviselő vesz részt a társaság vezetésében a 2019 és 2023 közötti időszakban. Újra megválasztották a társaság elnöki posztján Gál Zoltánt, a titkári pozícióban Rácz Szilárdot. Az alelnökök névsora is válto-

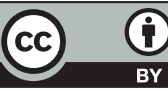


zatlan, a következő négy évben is Nagy Imre, Szabó Pál és Varga Attila töltik be ezt a tisztséget. Az elnökség tagjai Fábián Attila, Jakobi Ákos, Józsa Viktória, Kovács Sándor Zsolt, Lengyel Balázs, Mezei Katalin, póttagja Káposzta József lett. A Számvizsgáló Bizottság új elnöke Csomós György, tagjai Lipták Katalin, Vas Zsófia, póttagja Forman Balázs lett.

A közgyűlésen ünnepélyesen átadták a társaság által alapított díjakat, az MRTT Díszoklevelét harmadik alkalommal. Az elnökség e kitüntetéssel Kocziszky György professzor, a Miskolci Egyetem professor emeritusának, az MRTT Északmagyarországi tagozata leköszönő vezetőjének munkáját ismerte el. A tizenegyedik alkalommal meghirdetett Kiváló Ifjú Regionalista Díjat az MRTT tagozatvezetőkkel kibővített elnöksége Elekes Zoltánnak, a Szegedi Tudományegyetem Gazdaságtudományi Kar Közgazdaságtani és Gazdaságfejlesztési Intézete egyetemi adjunktusának ítélte oda a regionális tudomány művelésében elért értékes eredményeiért.

A közgyülést követően kilenc szekcióban mintegy 70 előadás hangzott el, melyek különböző területi léptékek alkalmazásával és tematikai fókuszokkal mutatták be a közép-európai regionális tudományi kutatások sokszínűségét. Az MRTT 2017 óta hirdeti meg nyilvánosan a szekciószervezés lehetőségét a vándorgyűlés első körlevelében, a 2019. évi rendezvényen az alábbi szekciók szervezték maguk köré az elöadókat:

- A területi elemzések elméleti és módszertani kérdései;

- Területi politika és tervezés Közép-Európában;

- A fogyasztás térbeli dimenziói;

- Térbeli és társadalmi egyenlőtlenségek Közép-Európában;

- Városfejlődés Kelet-Közép-Európában;

- Agrár-, környezet- és vidékkutatás;

- Társadalmi és térbeli egyenlőtlenségek Közép-Európában;

- Társadalmi tőke és területi egyenlőtlenségek;

- Az automatizálás társadalmi, gazdasági és regionális hatásai.

A köz- és vándorgyűlésről további információk és az előadások prezentációi a társaság honlapján (http://www.mrtt.hu/) érhetők el, a fotóalbum megtalálható az MRTT közösségi oldalán (https://www.facebook.com/mrtt.hu/). 